\title{
Reciprocity, Distancing, and Opportunistic Overtures: Women's Organisations Negotiating Legitimacy and Space in Bangladesh
}

\author{
Sohela Nazneen and Maheen Sultan
}

\begin{abstract}
By focusing on three different national level women's organisations in Bangladesh, this article looks at how the movements have used different strategies to become an effective voice for women's interests and empowerment at civil society and state levels. The importance of framing their issues in a non-contentious way, building alliances with like-minded groups and the strength of personal networks can be clearly seen. Reaching out to these diverse groups has meant the organisations at times making strategic choices, which allowed the groups to create space and legitimacy for their agenda. Relying on personal networks is shown to carry certain risks for sustainability and their ineffective engagement with political parties can reduce their influence, but ultimately their strategies for mobilising support and building constituencies has gained these organisations greater legitimacy and strength as advocates of women's issues.
\end{abstract}

\section{Introduction}

Women's organisations are vehicles for women to collectively formulate and voice their demands for rights and empowerment to their community, society and the state. This article shows how in the last decade women's organisations in Bangladesh became effective advocates of women's interests and empowerment by negotiating their position and establishing their strength and legitimacy. They were able to further the gender justice agenda at various levels and achieve increased recognition for these demands, and policy changes to ensure women's rights.

The 1990s are perceived by women's movements in Bangladesh as a 'golden age': a time when there was scope for raising feminist issues with the state. The Fourth World Conference on Women in Beijing in 1995 and the resulting Platform for Action encouraged the state to engage with these actors. There was increasing recognition of such organisations as legitimate interlocutors. In addition, the 1990s was a period of democratic transition, which meant that relations with the state were perhaps less confrontational. However, the state's attitude to gender equity has been contradictory: at times enacting progressive laws, yet at others being distinctly patriarchal and acting to sustain male advantage (Jahan 1995). The state is built on a gender and class hierarchical structure and patron-client relationships are still the dominant form of social organisation (Goetz 2001; Nazneen 2008a). Further, aid dependence and the politicisation of civil bureaucracy have severely undermined the capacity of the state. Almost all civil society organisations are polarised along party lines which undermines the capacity of the actors to articulate collective interests (Hassan 2002; Nazneen 2008b).

It is within this context that this article explores how three national level women's organisations Women for Women (WFW), Naripokkho (NP) and Bangladesh Mahila Parishad (BMP) mobilise various constituencies, including their own members, and negotiate with political parties, state bureaucracy and allies in civil society to achieve gender justice goals. These 
organisations are influential role models, and the diversity of strategies they use for constituency building and mobilising provide interesting insights. BMP, established in 1970, is the largest women's organisation in Bangladesh. It has a clear hierarchical command structure and strong links with leftist political parties. NP is a small organisation, formed in 1983, and committed to promoting women's equality to transform existing unequal power relations. It has a participatory style of decision-making. The smallest of the three, WFW, was established in 1973. It mainly focuses on policy advocacy.

Our research focused on two processes: how these organisations create support for their cause ('activation of commitment', Ryan 1992) and how they create meaning around issues. To explore this, a particular issue that each organisation was mobilising around, and on which they feel to have achieved some success, was selected. For BMP, it was political empowerment of women, principally how to increase the numbers of women in political office and local government. For NP, it was their campaign against acid violence, key to which was efforts to change social attitudes by working on the cultural representation of women. For WFW, it was their mobilisation around the implementation of the Convention on the Elimination of All Forms of Discrimination against Women (CEDAW) as an instrument that would help the women's movement in its attempt to make the state understand discrimination and its impacts and reform its laws.

The research process was reflexive, reiterative and action-oriented. Each organisation selected issues where they felt they were successful in mobilising support. Open-ended interviews with key people was a major source of data collection complemented with documentary analysis.

Previous research on organisational history and construction of organisational timelines helped to contextualise these issues within the broader societal context. Our insider status (one of us is a member of NP and the other has connections with both BMP and WFW) helped us to gain access, create space for the interviewees to reflect freely, and build an easier rapport since we were seen as people with knowledge of the organisations and the feminist movement. Our outsider perspective as researchers helped us to use a different lens to reflect on the organisations' actions and be aware of our own subjectivities.

\section{Packaging: 'naming and framing' the issues for mobilisation}

How an organisation packages or 'names and frames' an issue (Gamson 1975) plays a key role in building consensus among its members and allies. Naming and framing is influenced by the ideology of the organisation, the nature of its allies and supporters, and the type of emotion the organisation wants to evoke from its constituents (Taylor and Rupp 1991). Packaging has an influence over its success in building trust and solidarity amongst its members (Tarrow 1998).

The three organisations used different tactics in packaging their issues. The BMP framed the debate around women's political participation in terms of 'entitlement'. The emphasis for BMP's core constituents of members and locally elected female representatives was that in order for women to enjoy equal economic and social rights they needed to participate equally in decisionmaking. Barriers to women's political empowerment were presented as an injustice. The emphasis on these aspects aimed to do the following:

...[M]ake our members and women realise that unless women have the decision-making power they will not be able to change their position in other areas such as economic and social... The women representatives are aware about their rights being denied. They cannot carry out their duties because of the discrimination they experience at the hand of their male colleagues and at the institutional level. It creates anger and frustration among them about the injustice. We are there to provide support and to create a general awareness among women about this injustice. (interview, BMP1, 14 July 2008)

This injustice framing was crucial in building solidarity among members, representatives and women in general. These particular framing strategies were also used on other women's organisations and civil society as they tended to agree with demands regarding this issue.

However, for political parties and the state, BMP used more strategic methods by reminding them of their manifesto promises and highlighting gender biases within the political system.

The results of this packaging have been mixed. BMP has been successful in consolidating support amongst members and, to some extent, civil society. The campaign has evolved and 
spread: the issue is now widely recognised. However, it has had less success with the state and political parties. Holding the parties to account for promises made has been difficult. The parties do not see reneging as posing any significant electoral risk. In addition, BMP has been unable to address the perceived political cost of opposition from within parties and the potential loss of seats to other parties due to increasing reserved seats for women.

$\mathrm{NP}$ wanted to frame issues around the acid survivors' movement in a way that would mean the survivors' medical treatment, rehabilitation and justice needs are met by the state. But gender-sensitive service delivery and justice are not the only goals. They also wanted to create social awareness of the crime itself and to evoke empathy with the survivors as people. Thus, NP framed the issue as a matter of social justice, stressing the suffering experienced by survivors and their family and thereby creating space for and legitimating demands on healthcare and legal needs, but also on crime prevention. This framing emphasised the need to reflect on a society which gave rise to, enabled and tolerated such a heinous crime, whilst evoking empathy for and protectiveness towards the survivors among service providers. One NP activist explained:

\section{[O] ur target was to use emotions, and we used it to our advantage (advantage of the survivors), we encouraged the girls to speak out, to describe their traumas, pains, their family. It is difficult to ignore if you see it, if you hear it, if they are a person to you. (interview, NP2, 10 September 2008)}

Another reason for using this strategy was to circumvent the judgments made by these service providers about the moral character of the survivors (usually young women). This was particularly useful in court where these issues were raised by the defence. One NP member detailed her strategy:

If I had tried to challenge society's views about who a good girl is I would have hit a wall! Instead I tried to use emotions. I argued that whether one was involved did not mean that she deserved to have acid thrown at her. Her misdemeanour does not match the treatment she received. That the defendant's lawyer who is like her father/brother... should not be making such dirty insinuations... (interview, NP3, 14 September 2008)
Since the stress was on evoking empathy for the survivors, NP did not confront the social definition of the acceptable behaviour of a 'good girl'. Issues around adolescent romance and sexuality were explored with the survivors in 'safe' environments, not necessarily in the public domain (interview, NP4, 2 December 2008). However, NP did try to link the decision of a young woman to say no to a romantic proposal or the right to end a relationship to issues around bodily integrity and reproductive rights. This was raised during rallies and meetings held on International Women's Day and at other forums. The slogan used was 'Shorir amar, shidhanto amar' (My Body, My Choice).

WFW chose to frame the full ratification and implementation of CEDAW as a 'bill of rights for women' for its key civil society constituents (interview, WFW1, 30 July 2008). The different articles of CEDAW were linked to different articles of the Beijing Platform for Action (PFA), in order to contextualise and illustrate the nature of discrimination faced by women. This helped to concretise the issue at the grassroots level. A WFW member explained the process:

[W]e worked on CEDAW, where it came from, what does it say, how would women benefit. We went to the field. The first question we got was 'What is CEDAW?' We started by saying it was a dalil (legal document), and they thought it was a deed for land! So we decided to link it to women's rights issues, to the PFA... (interview, WFW3, 30 July 2008)

When presenting to the state, WFW deliberately chose to take a 'legalistic' approach in framing the issue. This was to avoid any accusations of being anti-Islamic and to create space for negotiation. The full ratification of CEDAW and the obligation to ensure gender equality were presented as mandatory since the state is a signatory to the Convention. A WFW member observed:

Our arguments are not based on emotions and nor are they targeted to evoke any emotional response, but to convince a person through logical argument... Our examples show how the religious personal laws can be discriminatory; why the government is accountable under CEDAW to address gender inequality... We used the Constitution to argue our case... we approached the government/state diplomatically, keeping the pressure on, because of the conservative elements... (interview, WFW1, 30 July 2008) 
WFW was able to keep pressure on the bureaucrats until the early 2000 s, without incurring any backlash from fundamentalist quarters. Personal connections may have influenced this. However, the stress on the state being under international legal obligation and on secularism have limited this issue to concerned women's groups, particular state officials, and certain sections of civil society. It has not been accepted by any of the political parties as a mainstream issue, neither has it been included in the wider civil society arena.

The organisations were successful in creating solidarity and support amongst their allies and other civil society groups due to only 'like-minded' groups being approached and packaging the issues in an uncontroversial manner. In negotiating with the state, the strategies helped the organisations avoid controversy and afforded them access, particularly as officials saw the issues as worthwhile and unthreatening. However, the 'packaging' strategies have had limited impact on creating space for a 'women's agenda' within the political parties. This is largely due to these issues remaining costly to address politically.

\section{Alliance-building with civil society: reciprocity, legitimacy and hierarchy}

The three organisations created alliances with civil society organisations, particularly women's organisations, as a means of building support for their issue, and strengthening the case that they were advocating, thus increasing pressure on the state. In the context of a polarised civil society alliance-building is risky. The legitimacy of an organisation to form an alliance and bring together a group of organisations around a specific issue has to be established, and is affected by whom it includes as an ally. An unspoken but implicit principle for alliances is that of reciprocity. Yet certain organisations have more weight through greater resources in terms of information, connections, mobilisation potential, visibility, etc. than others. These factors create tensions.

In the case of NP's movement against acid violence several types of alliances were formed, although not consciously created by NP. The most formal alliance has been the Acid Survivors Foundation (ASF). The main objective was to bring together the organisations working to combat acid violence while coordinating and bringing together services and advocacy acid survivors needed. NP decided that the role of service provision was not part of its mandate but wished to ensure that an advocacy platform be built around this. There were mixed views around the role the ASF would play, and NP was left feeling sidelined in the design and running of the Foundation, despite being one of its initiators. NP members and volunteers also promoted the building of networks among survivors, the main objective being to contribute to their sense of empowerment and facilitating the transition from being victims to being survivors. This networking continues.

Strategic alliances were created with the media to ensure more positive coverage. Although first attracted by the news value and sensationalism of the issue, some media institutions became genuinely committed to combating acid violence. Prothom Alo, a national daily newspaper, has since created a fund from which they make regular grants to acid survivors. Internally, NP had to struggle with issues of how the women would be represented and whether the sensationalisation would objectify them, but the survivors themselves wanted the media attention and felt in control of the interactions. The protection NP had wanted to give was neither needed nor wanted! (interview, NP4, 2 December 2008).

Other alliances included those with doctors and international organisations which served to mobilise resources for the acid survivors. A number of doctors, both in Bangladesh and overseas, became committed to providing care for the victims on a voluntary basis. This even led to the creation of a specialised burn unit at Dhaka Medical College Hospital.

For BMP, the Shamajik Protirodh Committee (SPC or Social Resistance Committee) was set up in 2001 in response to the then electoral violence against minorities. This then took on the issue of women's political empowerment. BMP felt that they would be stronger and less exposed to backlash if they were joined by other organisations. These alliances were seen as instrumental and context specific. A BMP member said, 'If a strong democratic government were to come along then slowly this platform will dissolve... it won't be as essential' (interview, BMP3, 29 July 2008).

$\mathrm{BMP}$ recognises that there are issues on which the SPG members respond more easily and on 
which they can have joint positions. There would seem to be an increasing acceptance of differences of approach. There are attempts to negotiate, discuss and reach a common understanding. When asked if there were conflicts between different organisations the response was, 'Each organisation deals with various issues in their own way. There are differences' (interview, BMP3, 29 July 2008). However it was perceived that now the organisations were more willing to work with each other:

\section{There is a greater unity among the organisations now... There is greater maturity now and demands are stronger... The blockages from government, i.e. not keeping their promises, has raised people's awareness... The alliance between organisations, the coalition has become much stronger. (interview, BMP1, 14 July 2008)}

BMP has been successful in garnering media interest in women's political participation. The media follow developments around the issue and can amplify the efforts of the women's organisations and hold up to public scrutiny the role the parties or the government plays or does not play in furthering women's interests.

WFW has formed and participated in fewer alliances than the other two organisations. One major exception was WFW's outreach work with women's organisations during the pre- and postBeijing process. At national level, WFW has to struggle to establish its identity and legitimacy to lead on a particular issue (as do other national level women's organisations), but little contestation comes from the organisations outside Dhaka which are happy to be included in as many alliances as possible.

An alliance significant for their work on CEDAW is with the Citizen's Initiative for CEDAW which drafted the Alternative report for the CEDAW Committee for 2009. This enables WFW to influence the analysis of the country context and use the platform to lobby for the removal of remaining reservations to CEDAW.

Lastly, while WFW has contacts in the media and working relations with the Nari Sangabik Kendra (Women Journalists Centre) for whom WFW has provided training, there is disappointment that their alliance with the media is not stronger and that the media has not taken on a more proactive and progressive role (interview WFW2, 16 August 2008).

Forming alliances is a common strategy with varied degrees of specialisation, sustainability, institutionalisation and effectiveness. These alliances have given the organisations additional visibility and credibility and increased their outreach beyond their organisational membership to smaller and often local level organisations. Expectations of mutual benefit and an unspoken principle of reciprocity have motivated members. Both NP and BMP were conscious of differences of opinion within the alliances and made conscious efforts to manage and address these differences.

\section{Relations with political parties: costs of engagement versus non-engagement}

There are divergent views in the women's movement about engagement with political parties and how far they can protect their autonomous voice. WFW and NP were similarly dismissive of the parties and felt they had very little to gain but everything to lose from engagement. BMP took the opposite view and saw the parties as allies which would espouse their cause. Consequently, they adopted two very different strategies to begin with but have now converged more after the BMP's disillusioning experience.

In spite of the success before the 2001 elections in getting both major parties to agree to reserved seats for women, neither party implemented this. The parties perceived the costs in terms of loss of male power to be higher than any potential benefits of ensuring women's effective representation. There has since been a gradual disillusionment and a feeling of betrayal as the various political parties have failed to deliver. 'Now we do not attend the meetings of the two big political parties. The nature of politics has changed. But we now have our own politics... the women's movement has its own politics' (interview, BMP3, 29 July 2008).

Strategically BMP still continues to work with the centrist and leftist parties and is willing to work with the party in power, trying to identify the right people to talk to. However, there is regret that none of the parties lives up to its expectations. The parties that BMP members 
feel reflect their political positions are felt to be very weak or even insignificant.

Both NP and WFW were concerned about credibility if they engaged with the parties. In a polarised national context, the organisations have had to 'jealously guard their non-partisan position' (interview NP4, 2 December 2008) and fight off party labels that have been applied to them from time to time.

NP consciously avoided engaging with political parties. An interviewee pointed out that the organisation 'did not know how to speak the language the politicians would understand' (interview, NP4, 2 December 2008). They did, however, interact with local politicians and found it easier to engage on concrete issues rather than with the national level party and its politics.

WFW also acknowledged that their relationship with political parties was weak. 'We were unable to use political contacts. We tried many ways through the NGO Coalition on Beijing Plus Five (NCBP), we arranged seminars, but never got their support' (interview, WFW2, 16 August 2008). There was no follow-up.

In conclusion, the organisations were all negative about the political parties and their lack of responsiveness and commitment to gender equality in general and to the issues they were pursuing. The political parties also do not seem to consider the women's organisations as part of their constituency and do not feel the need to justify their actions or lack thereof. BMP's agenda on political participation has become part of party rhetoric, but there does not seem to be any real commitment towards it. CEDAW has not entered the political vocabulary. However, issues of violence against women are increasingly addressed in the documents of the parties but whether this is in response to the women's organisations' demands or to the wider social mobilisation, is not clear.

While there might have been costs of engaging with political parties there are costs of not engaging with them. The influencing potential of the women's organisations is limited and they do not have access to the mainstream political party agenda. In the face of the current stalemate in relations with the parties, none of the three organisations seem to have come up with any new forms of engagement.

\section{Engagement with the state: opportunism or pragmatism?}

The women's movement in Bangladesh has strong views about engagement with the state, on what terms, for what purposes and also which state. Before 1990, the debate focused on whether engagement with an autocratic state meant legitimising it. Now, it has shifted to how and what types of engagement with the state can bring about greater accountability,

responsiveness and change.

For WFW, especially on an issue such as CEDAW, the state plays a primary role. WFW was able to benefit from close relations with the bureaucracy and from the presence of their own members in positions of influence at crucial points in time. The argument for the full implementation of CEDAW was based on a reference to the national Constitution. WFW showed that it was in the government's interest to first ratify CEDAW, then regularly report on it and move towards removing the remaining reservations.

International reputation has always been important to the government, whichever the party in power, and the costs were perceived to be limited since it has been able to sign such conventions without needing to implement them. Women's organisations have tried to increase the costs by using the CEDAW Committee platform to publicly shame the government for not living up to its promises to remove the reservations and undertake modification of national laws to be in conformity with CEDAW.

The rationale behind NP's strategy to make the state responsible for ensuring women's rights is sustainability: 'Because we might be here today as an organisation (and gone tomorrow), but the government machineries will stay...' (interview, NP3, 14 September 2008). One of the interviewees explained: 'We were not against the state. Our role was to enable the state. So the issue was developing capacity' (interview, NP3, 14 September 2008). They felt that public offices needed to be strengthened and encouraged to deal with cases of acid violence. An interviewee explained: 'We cannot create an alternative system. We need to fix the (existing) system' (interview, NP3, 14 September 2008).

Invariably, influencing the government is difficult, time-consuming and laborious. Experience has shown that there is a big gap between policy and 
implementation and that unless there is constant pressure, many of the legal or policy level gains remain on paper. NP's strategy emphasised the creation of working relations with various levels of the state - for example police and hospitals. A member commented on government officials' responsiveness to the issue of acid violence and felt that it was much more than the organisation had experienced before (which can be explained by the framing of the issue) and thought that 'active citizenship' can lead to a qualitative improvement in services (interview, NP4, 2 December 2008).

Coming from a political background, BMP found it harder to engage with the state, especially during periods when they did not approve of the political ideology of the regime. After initial reluctance, BMP decided to work strategically with the state apparatus and continued to take up opportunities to petition and lobby the state. An interviewee explained:

...If we want to change laws then we have to go to the 'State apparatus'. We will have to approach the PM and ministers. We cannot avoid the state structure to bring about such changes... (interview, BMP2, 18 July 2008)

The pressure was kept up despite their reluctance to engage and fears of being negatively received: 'kanai diaichi tula, pithai bendhaichi kula' ('we shut our ears with cotton and padded our back against blows'; interview, BMP2, 18 July 2008).

BMP interviewees pointed out that the state acknowledges them as legitimate spokespeople for the women's movement: 'We are sometimes called by the State to give our opinions on various subjects, for example the Women's Development Policy' (interview, BMP1, 14 July 2008). However, on the issue of political empowerment the State never called BMP but they have approached the state:

We have worked with all the political governments. In the last government, we were never able to meet the Prime Minister but [met] her Law Minister. In the AL [Awami League] government, we were able to meet the Prime Minister. The impact in both cases was nil. But for a demand such as ours we had to approach the government... (interview, BMP2, 18 July 2008)
All three organisations have been able to engage strategically and substantively with the state and bring about various changes. They have tried to establish state responsibilities in a number of areas, recognising that some issues can only be done by the state. The organisations have been both pragmatic and opportunistic in their engagement, and the state would seem to be dealing with them in the same manner, calling on them as and when needed and choosing to ignore them when it suited them to do so.

\section{Personal networks: access and sustainability issues}

Given the social and political context of Bangladeshi society, personal networks emerged as a key tool for all three organisations. Personal connections, either familial or other types, create a sense of obligation to reciprocate and evoke trust, which are key factors in influencing people to join and to act (Tarrow 1998). In the case of the three organisations, these networks helped to open up policy and organisational spaces to present their case.

NP used personal networks to approach the state to overcome initial resistance in accessing state service provision; to manage disagreements among the service providers about NP's role; and to create an immediate impact on the issue. Initially, NP's proposal to monitor healthcare service providers and police stations was resisted by government employees. They feared that monitoring could reveal failings. However, the members' personal relations with hospital and police heads ensured the required permission.

Many of the WFW members are academics and have family or former students working within the state bureaucracy and this created an opportunity for them to lobby key people. A WFW member explained:

All of us have links with the bureaucracy... [A] lot of the government secretaries are our students. Some of them were our juniors (studied at the same university). Our family members work as state officials. We used that network... If we asked for a meeting, if we made a request... they could not just overlook it.

(interview, WFW1, 30 July 2008)

Moreover, in the 1990s when WFW started working on CEDAW, many of the WFW members were in key positions. This allowed them to bring 
up gender equity issues in various state forums, build rapport with key officials and identify obstacles. One WFW member observed:

We had the right people in the right places. They were in strategic positions... We were in the Planning Commission, also working in donor agencies. We were able to bring in gender issues at different levels of policymaking process. Since we were in key positions, we did not face bureaucratic resistance. We could negotiate... (interview, WFW2, 16 August 2008)

Interviewees from BMP pointed out that in dealings with the state, personal networks are the primary strategy that produces results. Garnering support among the political parties was also done on the basis of personal networks. One interviewee explained that personal connections with party leadership were used on a strategic basis:

We try and work with people who are progressive within the party, whom we may have known... (interview, BMP2, 18 July 2008)

The presence of particular individuals within a group determined whether BMP would ask them for cooperation. The interviewees explained that this selection approach was due to the partisan nature of Bangladeshi civil society and the cost it implies. One BMP member commented:

We do not approach groups, we approach individuals who are progressive, who believe in women's empowerment... Given that a lot of the groups can be partisan, our allies are not groups but specific persons who we can trust... (interview, BMP2, 18 July 2008)

Undeniably, the strength of personal networks facilitated advocacy and aided mutual reciprocity in building alliances. It was also effective in mobilising insiders within the state structure and overcoming resistance within state bureaucracy. However, it may also adversely influence sustainability and effectiveness, if gains made in negotiating with the state or political parties rely on personal links with individuals; if the individuals leave, then the organisations' effectiveness may diminish. All interviewees recounted instances where this has been the case. In spite of these risks in the context of Bangladesh this remains an effective strategy.

\section{Conclusions}

Our analysis shows that strategic packaging and engagement with supporters/allies have allowed these organisations to establish legitimacy of voice and space. Their strategic engagement allowed them to promote demands for gender justice and mobilise a wider audience than their own membership and like-minded groups. The fact that they were able to make opposing these agendas difficult for other organisations shows the strength of the constituency-building process.

Though these organisations mobilised supporters for different causes, their strategies in dealing with the state, political parties and other civil society groups were similar. It is this similarity that draws attention to the importance of wider contextual factors, i.e. polarised civil society, nature of the state, etc., that influence the decisions of organisations in movement building. Alliance-building is not without issue; the power asymmetries and how concerns for legitimacy fuel the need of the larger organisations to control the agenda-setting process indicate the influence of these factors. Equally personal networks, although playing a key role in mobilising on an issue, raise questions about sustainability. Moreover, non- or ineffective engagement with political parties has had certain costs in terms of reducing influence.

The strategies used to mobilise support and build constituencies in favour of the specific demands has made significant contributions towards advancing the agenda for women's empowerment in Bangladesh. The analysis has shown that while doing so the women's organisations we researched also gained greater legitimacy and strength for themselves as advocates of women's interests. Strategies for empowering women need to take into account the role played by such organisations as mediators and channels of women's voice and demands, and engage with and support them more actively as champions of change. 


\section{References}

Gamson, W. (1975) The Strategy of Social Protest, Illinois: Homewood

Goetz, A-M. (2001) Women Development Workers, Dhaka: University Press

Hassan, M. (2002) 'The Demand for Second Generation Reform: The Case of Bangladesh', PhD Thesis, University of London

Jahan, R. (1995) 'Men in Seclusion and Women in Public: Rokeya's Dreams and Women's Struggles in Bangladesh', in A. Basu (ed.), The Challenges of Local Feminism, Boulder, CO: Westview Press

Nazneen, S. (2008a) 'Gender Sensitive Accountability of Service Delivery NGOs:
BRAC and Proshika in Bangladesh', PhD Thesis, Brighton: IDS

Nazneen, S. (2008b) 'Group Discrimination at Elections: Bangladesh', in D. Mendis (ed.), Electoral Process and Governance in South Asia, London and New Delhi: Sage

Ryan, B. (1992) Feminism and the Women's Movement, London: Routledge

Tarrow, S. (1998) The Power in Movement, Cambridge: Cambridge University Press Taylor, V. and Rupp, L.J. (1991) 'Researching Women's Movements', in M.M. Cook and J.A. Fonow (eds), Beyond Methodology, Indiana: Indiana University Press 